\title{
Peningkatan Keaksaraan Awal dan Pengenalan Kemampuan Berhitung Dasar Anak Usia Dini dengan Menggunakan Model Maya Hasyim
}

\author{
HENI NAFIQOH ${ }^{1}$, EMA APRIANTI2, EUIS ETI ROHAET|3 \\ Program Studi Pendidikan Pendidikan Guru Pendidikan Anak Usia Dini \\ Institut Keguruan dan IImu Pendidikan SILIWANGI \\ E-mail: heninafiqoh@ikipsiliwangi.ac.id, emaaprianti@ikipsiliwangi.ac.id, e2rht@yahoo.com
}

DOI: https://doi.org/10.29313/ga.v3i1.4813

\begin{abstract}
The objectives to be achieved through this research are to analyze and describe the implementation of the Maya Hasim implementation of the word through Kindergarten to improve the development of early literacy skills and basic counting. Results of the Maya Hasim application of words and their effects on Kindergarten. Drivers and obstacles to the application of Maya Hasim words in an effort to improve the development of early literacy skills and calculate the basis for children in Kober. The research method used is qualitative research with the consideration that the research subject is TK Tridaya Cimahi students. This study shows that the efforts of early literacy skills and basic counting through the application of the Maya Hasim Hasim model were useful. Children can imitate what the teacher has shown and done. In order for children to emulate all the activities instructed by the teacher, the teacher must regulate the application of the Maya Hasim model in explaining their activities. The application of the Maya Hasim model is very influential on the concentration of children. The application of the model Maya Hasim makes children interested in learning, children will become more enthusiastic about learning.
\end{abstract}

Keywords: Early Literacy and Basic Counting.

\begin{abstract}
Abstrak
Tujuan yang ingin dicapai melalui penelitian ini adalah untuk menganalisa serta mendeskripsikan pelaksanaan penerapan maya hasim melalui TK untuk meningkatkan pengembangan kemampuan keaksaraan awal dan berhitung dasar. Hasil penerapan maya hasim dan pengaruhnya terhadap TK. Pendorong dan penghambat penerapan maya hasim dalam upaya peningkatan pengembangan kemampuan keaksaraan awal dan berhitung dasar bagi anak di TK. Metode Penelitian yang di gunakan Penelitian kualitatif dengan pertimbangan bahwa subjek riset adalah Siswa TK Tridaya Cimahi. Penelitian ini menunjukkan hasil bahwa upaya kemampuan keaksaraan awal dan berhitung dasar melalui penerapan model maya hasim. Anak dapat meniru apa yang telah ditunjukkan dan dilakukan oleh guru. Agar anak dapat meniru semua kegiatan yang diinstruksikan oleh guru, guru harus mengatur penerapan model maya hasim dalam menjelaskan kegiatannya. Penerapan model maya hasim sangat berpengaruh pada konsentrasi anak. Penerapan model maya hasim membuat anak tertarik untuk mengikuti pembelajaran, anak akan menjadi lebih antusias mengikuti pembelajaran.
\end{abstract}

Kata Kunci: Keaksaraan Awal dan Berhitung Dasar. 


\section{Pendahuluan}

Salah satu langkah pertama untuk menjadi pembaca yang sukses adalah belajar mengenali huruf abjad. Implementasi orangtua atas hasil belajar yaitu anak dapat menguasai membaca dan, menulis dan berhitung. Orangtua tersebut berkeinginan dengan alasan mengingat kemampuan kekasaraan awal dan berhitung dasar dan menulis merupakan hal mendasar yang harus dipupuk sejak dini untuk dijadikan bekal bagi seorang anak memasuki dunia pendidikan. Lebih dari itu, kemampuan kekasaraan awal dan berhitung dasar merupakan modal utama seorang anak untuk membuka jendela masa depan, sebuah langkah awal menguasai ilmu pengetahuan.

Menurut Errifa Susilo (2013), menyebutkan bahwa belajar kekasaraan awal dan berhitung dasar bukanlah merupakan suatu tindakan alamiah dari seorang anak. Kemampuan kekasaraan awal dan berhitung dasar pada seorang anak tidaklah didapatkan begitu saja seiring perkembangan usianya. Untuk mendapatkan kemampuan ini pada seorang anak, diperlukan suatu proses belajar. Lingkungan dan orangtua memegang peranan penting dalam proses pengenalan kekasaraan awal dan kata-kata yang pada awalnya akan ditangkap oleh anak sebagai bahasa lisan. Dalam proses pengenalan ini, anak belum sampai pada proses belajar, hanya mengenal dan memahami bunyi-bunyian itu.

Yang tidak difahami dan diketahui orang tua adalah bahwa "prinsip huruf abjad" merupakan proses awal seorang anak mampu membedakan karakter satu huruf dengan huruf lainnya yang bila dirangkaikan akan menimbulkan keragaman bunyi. Sehingga menjadi proses ini adalah tahap dimana anak mulai mengidentifikasi bunyi yang ada dalam kata, setelah itu barulah dapat diajarkan bagaimana huruf-huruf alfabet itu dapat membentuk suatu kata yang bermakna berbeda satu dengan lainnya.

Namun demikian kendala banyak sekali kendala yang dihadapi yaitu banyak anak yang menjadi bosan dan kehilangan konsentrasi. Akibatnya, hanya sekitar $20 \%$ dari jumlah anak dalam kelas yang mampu menyelesaikan tugas dan menguasai ketiga area kegiatan setiap harinya. "Dalam perlunya motivasi dan atensi dari pendidik untuk meningkatkan dan memotivasi anak dalam belakar mengenal kekasaaran dan berhitung" (Dardjowidjojo, 2003:300). Praktik pengajaran keaksaraan di dalam kelas juga memuat beberapa kelemahan. Anak hanya mengikuti buku materi belajar untuk belajar menulis masih dengan pembelajaran konvensional yang sudah ditentukan sebelumnya.

Tujuan mengenalkan huruf abjad adalah agar anak-anak memahami kekasaraan awal, dapat menghubungkan kata-kata dan makna. belajar mengenal keaksaraan awal adalah proses yang relatif panjang yang dimulai sangat awal dalam pembangunan dan jelas sebelum anak-anak memasuki sekolah formal. Anak-anak yang menerima stimulasi pengalaman keaksaraan sejak lahir dan seterusnya tampaknya memiliki kelebihan dalam hal pengembangan kosa kata, memahami tujuan kekasaraan awal dan berhitung dasar, dan mengembangkan kesadaran keaksaraan cetak dan konsep. Anak-anak yang telah belajar untuk mengenali kekasaraan awal dan berhitung dasar seperti kebanyakan anak-anak prasekolah akan memiliki lebih sedikit untuk belajar pada masuk sekolah. Belajar dengan model maya hasim, sehingga anak-anak yang berorientasi ke keaksaran awal prinsip atau cara menghubungkan huruf dan bunyi. Semakin awal mengenalkan kekasaaran dan berhitung dasar pada anak, dengan hanya berbicara kepada anak, kekasaraan awal dan berhitung dasar untuk anak, dan kemudian mendengarkan, menanggapi komunikasi anak semakin baik pula ketika waktunya tiba untuk belajar siap. Berdasarkan latar belakang masalah yang telah dikemukakan di atas maka di pandang cukup penting untuk mengadakan penelitian tentang:" Penerapan Model Maya Hasim Dalam Upaya Peningkatan Kekasaraan Awal Dan Pengenalan Kemampuan Berhitung Dasar Anak Usia Dini Di Tk Tridaya Cimahi ".

\section{Tinjauan Pustaka}

\section{Pengertian Penerapan model maya hasim}

Model Maya Hasim adalah strategi pengembangan pembelajaran kekasaraan khususnya pra keaksaraan bagi anak usia 5-6 tahun yang dijabarkan dalam wmap tahapan yaitu Maknai, Hayati, Hapalkan dan kenali Simbol. Sri Lilis dkk (2016:12) Pada hakikatnya Pembelajaran memnggunakan model maya hasim ini berprinsip bahwa pembelajaran dilakukan melalui kegiatan bermain dan disesuaikan dengan capaian perkembangan sang anak, nantinya anak akan menambah kosakata melalui interaksinya dengan lingkungan sekitarnya melalui teman atau keluarganya. Guru atau pendidik berperan sebgai fasilitator dan motivator bagi anak dan dilaksanakan secara kontekstual.Untuk penerapannya sendiri, model 
pembelajaran maya hasim ini diawali dengan penyusunan rencana bermain mulai dari pemetaan tema dan penetapan kegiatan bermain. Adpaun tahap berikutnya yakni pelaksanaan bermain, dimulai dengan pembukaan, dilanjut dengan kegiatan Inti dan setlah itu penutup, yang terakhir ialah melalukan penilaian. Di tahap penilaian ini, keseluruhan aspek perkembangan masing-masing anak perllu dikaji untuk melihat sejauh mana anak berkembang. Bahasa merupakan sarana berkomunikasi dengan orang lain, urutan kata-kata yang dapat digunakan untuk menyampaikan informasi mengenai suatu hal. Antara 5-6 tahun, ketika pembelajaran keaksaran awal anak mulai memahami dari 6-8 kata, dan mualai dapat menghitung mengurangi dan menambahkan bilangan sederhana serta dapat menjelaskan arti kata yang sederhana, mengetahui lawan kata, dapat menggunakan kata penghubung, depan dan sambung. Anak usia PAUD juga telah mengenal tulisan sebagai label atau nama. Oleh karena itu, tulisan dapat dimanfaatkan sebagai alat peraga atau media bercerita. Lebih dianjurkan, tulisan yang dipergunakan berupa kata utuh dengan bentuk tulisan yang familiar bagi anak. Ada beberapa tujuan pengembangan bahasa yang usia PAUD, diantaranya: Depdiknas (2004) mengemukakan tujuan bahasa di PAUD adalah sebagai berikut:

Dari tujuan di atas dijabarkan kedalam hasil belajar yang harus dicapai oleh anak usia PAUD. Hasil belajar itu adalah sebagai berikut:

a. Dapat mendengarkan dan membedakan bunyi suara, bunyi bahasa dan pengucapannya

b. Dapat mendengar dan memahami kata dan kalimat sederhana

c. Dapat bekomunikasi secara lisan

d. Memperkaya kosa kata yang diperlukan untuk berkomunikasi sehari-hari meliputi kata kerja, kata benda, kata sifat dan keterangan waktu.

e. Dapat mengenal symbol-simbol sederhana (pra menulis)

f. Dapat menceritakan gambar

g. Mengenal bahwa ada hubungannya antara bahasa lisan dengan tulisan.

Kondisi tersebut menunjukkan berfungsi dan berkembangnya sel sel syaraf otak. Dalam hal ini para ahli syaraf meyakini bahwa jika gejala-gejala munculnya potensi tidak diberikan rangsangan untuk berkembang kearah positip maka potensi-potensi tadi akan kembali menjadi potensi tersembunyi dan lambat laun fungsinya akan berkurang hingga sel syaraf mati. Aspek-aspek perkembangan itu tidak berkembang secara sendiri, melainkan saling berkorelasi dan berhubungan antara yang satu dengan yang lainnya karena bersifat integratif yang tidak bisa dipisahkan antara satu dengan yang lainnya.

\section{Perkembangan Kemampuan Kekasaraan awal dan berhitung dasar Awal Anak Usia PAUD}

Keaksaraan awal ialah kekasaraan awal dan berhitung dasar yang diajarkan secara terprogram (secara formal) kepada anak pra sekolah. Durkin dalam (Endrianti, 2007) "menyatakan bahwa tidak ada efek negatif pada anak-anak dari keaksaraan awal". Anak-anak yang telah belajar kekasaraan awal dan berhitung dasar sebelum masuk SD pada umumnya lebih maju disekolah dibandingkan dengan anak-anak yang belum pernah memperoleh keterampilan keaksaraan awal. Steinberg dalam (Endrianti, 2007) menggemukakan bahwa setidaknya ada empat keuntungan mengajar anak keaksaraan awal dilihat dari segi proses belajar mengajar : (1) belajar keaksaraan awal memenuhi rasa ingin tahu anak, (2) situasi akrab dan informal di rumah dan di kelompok bermain atau Taman Kanak-kanak merupakan faktor yang kondusif bagi anak untuk belajar, (3) anakanak usia dini pada umumnya perasa dan mudah terkesan, serta dapat diatur, (4) anak-anak yang berusia dini dapat mempelajari sesuatu yang mudah dan cepat.

Glenn Doman dalam Anna Yulia (2005:19) "Kekasaraan awal dan berhitung dasar merupakan salah satu fungsi yang paling penting dalam hidup dan dapat dikatakan bahwa semua proses belajar didasarkan pada kemampuan kekasaraan awal dan berhitung dasar". Kemampuan kekasaraan awal dan berhitung dasar merupakan salah satu kemampuan individu dalam memahami kebutuhan mengenai suatu informasi karena pada dasarnya setiap individu mempunyai dorongan untuk selalu ingin tahu, dengan rasa ingin tahunya itu individu berusaha memenuhinya melalui kegiatan kekasaraan awal dan berhitung dasar.

Membangun minat pada kegiatan kekasaraan awal dan berhitung dasar, sejak awal dilakukan sebelum melakukan pengenalan kekasaraan awal dan berhitung dasar, bila anak sudah ingin kekasaraan awal dan berhitung dasar usahakan untuk melayaninya selalu dengan mengenalkan huruf. Kemampuan kekasaraan awal dan berhitung dasar merupakan kemampuan yang sangat penting dalam kehidupan di masa lalu, sekarang maupun yang akan datang. Kekasaraan awal dan berhitung dasar adalah sesuatu yang wajar dam menyejarah (Endrianti, 2007). Gray dalam (Hawadi, 2001: 36) menyebutkan beberapa komponen kekasaraan awal dan berhitung dasar, yaitu : 


\section{Pengenalan kata-kata}

Disini penekanannya pada perkenalan persamaan atau antara apa yang diucapkan dan apa yang ditulis sebagai simbol, istilahnya decoding.

\section{Pengertian}

Selain mengenali simbol dan dapat mengucapkan dalam kekasaraan awal dan berhitung dasar yang terpenting adalah mengerti apa yang dibaca.

3. Reaksi

Diharapkan ada reaksi terhadap hal yang dilihat Menurut Thomson (1970:108) dalam (Hawadi, 2001: 37) waktu yang paling tepat untuk belajar kekasaraan awal dan berhitung dasar adalah saat anak duduk di PAUD. Pada masa ini rasa ingin tahu anak berkembang sehingga anak banyak melontarkan pertanyaan pertanyaan.

Anak juga sudah lebih siap memerima hal-hal yang dilihatnya di sekolah. Disamping itu, keterikatan anak pada hal-hal yang konkret semakin berkurang, dan sebaliknya kemampuan mereka berkembang menjadi lebih abstrak. Untuk itu, anak sudah dapat dilibatkan pada simbol-simbol.

\section{Metodologi Penelitian}

Penelitian ini menggunakan metode kualitatif, yaitu melakukan penelitian dengan tujuan ingin menggambarkan masalah dan melakukan analisis terhadap masalah.

Menurut Corbin, (2007:4) menulis,"istilah penelitian kualitatif dimaksudkan sebagi jenis penelitian yang temuan-temuannya tidak diperoleh melalui prosedur statistik atau bentuk hitungan lainnya."

Untuk memperoleh data-data yang berkenaan dengan judul penelitian, penulis menggunakan teknik pengumpulan data melakukan pengamatan dan observasi sebagai berikut:

\section{Pengamatan}

Peneliti berada di PAUD dan mengamati semua aktivitas dan proses pembelajaran dari tempat tertentu, peneliti mengamati dengan seksama dan cermat. Dwilestari (2012:78)

\section{Wawancara}

Yaitu percakapan yang dilakukan dua pihak yaitu pewawancara (interviewer) yang mengajukan pertanyaan dan terwawancara (interviewee) yang memberikan jawaban dengan maksud tertentu yang berhubungan dengan masalah yang diteliti. Penulis melakukan wawancara dengan Ketua Kober dan staf pengajar di Kober tersebut.

\section{Observasi}

Yaitu penulis melakukan kunjungan ke tempat penelitian dan melakukan pengamatan yang berkaitan dengan tujuan penelitian tersebut.

\section{Studi Dokumentasi}

Dokumentasi adalah setiap bahan tertulis baik bersifat resmi ataupun tidak. Penulis berusaha memahami dan menganalisa dokumen-dokumen tertulis yang diperoleh dari tempat penelitian untuk selanjutnya dikembangkan pada bagian bab tertentu. Sedangkan instrumen pengumpulan data dalam penelitian ini yaitu:

a. Pedoman wawancara yang terdiri dari beberapa daftar pertanyaan yang berhubungan dengan judul penelitian.

b. Pedoman observasi. Pedoman tersebut berisi mengenai gambaran nyata yang akan dijadikan objek penelitian diantaranya adalah bagaimana kondisi objek yang akan diteliti tersebut.

c. Pedoman dokumentasi

\section{Pembahasan}

Pada bagian ini akan dibahas hasil penelitian Hasil observasi pada hari Rabu tanggal 11 April 2019, menunjukkan dari 6 orang anak sebagai kasus bahwa 5 anak sudah Baik anak mampu melakukan semua kegiatan tanpa bantuan guru yaitu mencocokkan gambar dengan huruf awal. 1 orang anak cukup mampu melakukan semua kegiatan pembelajaran, namun masih memerlukan sedikit bantuan guru, setelah diadakannya perbaikan dalam proses kegiatan Pengembangan keaksaaraan awal yang lebih menarik dengan menggunakan Model pembelajaran maya hasim keaksaraan awal dan berhitung sederhana lebih baik dan anak lebih memahami serta bisa melakukan kegiatan. Hasil observasi pada hari Rabu tanggal 11 April 2019, menunjukkan dari 6 orang anak sebagai kasus bahwa semua anak sudah Baik anak mampu melakukan semua kegiatan tanpa bantuan guru yaitu menyebutkan kelompok gambar dengan huruf awal yang sama. setelah diadakannya perbaikan dalam proses kegiatan Pengembangan keaksaaraan awal yang lebih menarik dengan menggunakan Model pembelajaran maya hasim keaksaraan awal dan berhitung sederhana lebih baik dan anak lebih memahami serta bisa melakukan kegiatan dengan baik.Hasil observasi pada hari Rabu tanggal 11 April 2019, menunjukkan dari 6 orang anak sebagai kasus bahwa semua anak sudah Baik anak mampu 
melakukan semua kegiatan tanpa bantuan guru yaitu mengenal suara huruf awal dari nama-nama gambar binatang. Setelah diadakannya perbaikan dalam proses kegiatan Pengembangan keaksaaraan awal yang lebih menarik dengan menggunakan Model pembelajaran maya hasim keaksaraan awal dan berhitung sederhana lebih baik dan anak lebih memahami serta bisa melakukan kegiatan dengan baik.Hasil observasi pada hari Rabu tanggal 11 April 2019, menunjukkan dari 6 orang anak sebagai kasus bahwa 5 anak sudah Baik anak mampu melakukan semua kegiatan tanpa bantuan guru yaitu memahami hubungan gambar dengan bentuk gambar. 1 orang anak cukup mampu melakukan semua kegiatan pembelajaran, namun masih memerlukan sedikit bantuan guru, setelah diadakannya perbaikan dalam proses kegiatan Pengembangan keaksaaraan awal yang lebih menarik dengan menggunakan Model pembelajaran maya hasim keaksaraan awal dan berhitung sederhana lebih baik dan anak lebih memahami serta bisa melakukan kegiatan. Hasil observasi pada hari Rabu tanggal 11 April 2019, menunjukkan dari 6 orang anak sebagai kasus bahwa semua anak sudah Baik anak mampu melakukan semua kegiatan tanpa bantuan guru yaitu menyusun atau merangakai nama sendiri dengan gambar. 6 orang anak mampu melakukan semua kegiatan pembelajaran, namun masih memerlukan sedikit bantuan guru, setelah diadakannya perbaikan dalam proses kegiatan Pengembangan keaksaaraan awal yang lebih menarik dengan menggunakan Model pembelajaran maya hasim keaksaraan awal dan berhitung sederhana lebih baik dan anak lebih memahami serta bisa melakukan kegiatan.Berdasarkan Semua data observasi diatas, dapat disimpulkan bahwa keterampilan Pengembangan keaksaaraan awal anak TK Tridaya sudah berhasil. Data tersebut menunjukkan bahwa sebagian besar anak sudah mampu melakukan semua kegiatan pembelajaran untuk itu peran guru untuk memberikan perbaikan dalam proses kegiatan Pengembangan keaksaaraan awal yang lebih menarik harus lebih ditingkatkan lagi. (Hasil Observasi Hari Rabu Tanggal 11 April 2019).Keterampilan Pengembangan keaksaraan awal anak yang belum optimal adalah anak dapat menyebutkan huruf vokal dan konsonan dengan menggunakan model maya hasim. Sebagian besar kemampuan Pengembangan keaksaaraan awal anak pada ini berada pada kemampuan cukup.Dari hasil observasi yang telah dilakukan terdapat peningkatan yang cukup baik pada keterampilan Pengembangan keaksaaraan awal anak dalam setiap tindakan pada setiap kegiatannya. Hasil observasi dari peningkatan keterampilan Pengembangan keaksaaraan awal anak dilihat dengan membandingkan hasil setiap indikator penilaian yang dicapai baik oleh anak pada observasi awal dengan hasil dari setiap kegiatan.

yang telah dipaparkan di atas. Kondisi Meningkatkan Kemampuan keaksaraan awal dan berhitung dasar di TK Tridaya Cimahi Sebelum melakukan pembelajaran, kepala sekolah dan guru TK Tridaya Cimahi membuat perencanaan pembelajaran. Perencanaan pembelajaran yang dilakukan di TK Tridaya Cimahi mengacu pada Permendinas No.137 Tahun 2013 "yang didalamnya tercantum standar kompetensi, hasil belajar dan indikator untuk mengembangkan seluruh aspek perkembangan anak meliputi moral dan nilai-nilai agama, sosial, emosional, kemandirian, kemampuan berbahasa, kognitif, fisik motorik dan seni". Selain itu, materi yang diberikan kepada anak disesuaikan dengan tema-tema dari Departemen Pendidikan Nasional yang dirancang dalam Rencana Pelaksanaan pembelajaran Mingguan (RPPM) dan dikembangkan kembali dalam Rencana Pelaksanaan Pembelajaran Harian (RPPH).

Kegiatan pengembangan keterampilan Meningkatkan Kemampuan keaksaraan awal dan berhitung dasar di TK Tridaya Cimahi belum menggunakan penerapan model maya hasim. Hasil observasi menunjukkan bahwa Meningkatkan Kemampuan keaksaraan awal dan berhitung dasar di TK Tridaya Cimahi masih merujuk pada lembar kerja. Selain itu, media yang dipergunakan untuk menunjang Meningkatkan Kemampuan keaksaraan awal dan berhitung dasar ini pun sangat minim. Diakui oleh guru di TK Tridaya Cimahi, bahwa sampai saat ini para guru masih kesulitan dalam mengajarkan Meningkatkan Kemampuan keaksaraan awal dan berhitung dasar kepada anak-anak, dan juga belum menemukan cara dan media pembelajaran yang tepat dalam kegiatan Meningkatkan Kemampuan keaksaraan awal dan berhitung dasar di TK Tridaya Cimahi. Sehingga kegiatan Meningkatkan Kemampuan keaksaraan awal dan berhitung dasar yang diterapkan di TK Tridaya Cimahi masih menggunakan metode konvensional atau pengerjaan latihan di buku tulis. Kondisi pembelajaran seperti ini lambat laun akan menghambat perkembangan anak selanjutnya, karena tidak sejalan 
dengan yang di ungkapkan oleh Solehuddin (Sriningsih, $2008: 3-4$ ) bahwa :

Namun, menurut Depdiknas (2004:2) ada beberapa prinsip yang harus diperhatikan oleh guru saat memberikan permainan Meningkatkan Kemampuan keaksaraan awal dan berhitung dasar pada anak. Prinsip-prinsip tersebut adalah sebagai berikut :

a. Permainan Meningkatkan Kemampuan keaksaraan awal dan berhitung dasar diberikan secara bertahap, diawali dengan menggambarkan bendabenda atau pengalaman peristiwa kongkrit yang dialami melalui pengamatan terhadap alam sekitar,

b. Pengetahuan dan keterampilan pada permainan Meningkatkan Kemampuan keaksaraan awal dan berhitung dasar diberikan secara bertahap menurut tingkat kesukarannya, misalnya dari kongkrit ke abstrak, mudah ke sukar, dan dari sederhana ke yang lebih kompleks,

c. Meningkatkan kemampuan keaksaraan awal dan berhitung dasar akan berhasil jika anak-anak diberi kesempatan berpartisipasi dan dirangsang untuk menyelesaikan masalah-masalahnya sendiri,

d. Permainan Meningkatkan Kemampuan keaksaraan awal dan berhitung dasar membutuhkan suasana menyenangkan dan memberikan rasa aman serta kebebasan bagi anak. Untuk itu diperlukan alat peraga/media yang sesuai dengan benda sebenarnya (tiruan), menarik dan bervariasi, mudah digunakan dan tidak membahayakan,

e. Bahasa yang digunakan di dalam pengenalan konsep Meningkatkan Kemampuan keaksaraan awal dan berhitung dasar seyogyanya bahasa yang sederhana dan jika memungkinkan mengambil contoh yang terdapat di lingkungan sekitar anak,

f. Dalam meningkatkan kemampuan keaksaraan awal dan berhitung dasar anak dapat dikelompokkan sesuai tahap penguasaannya yaitu tahap konsep, masa transisi dan lambang. Penerapan maya hasim untuk meningkatkan keterampilan Meningkatkan Kemampuan keaksaraan awal dan berhitung dasar anak dalam penelitian ini dilaksanakan dengan melalui dua kali observasi. Kondisi pembelajaran kegiatan Meningkatkan Kemampuan keaksaraan awal dan berhitung dasar dengan menggunakan penerapan model maya hasim sudah mulai terkondisikan. Anak sudah bisa berkonsentrasi untuk memperhatikan instruksi dari guru dan mau mempraktekkan langsung kegiatan Meningkatkan
Kemampuan keaksaraan awal dan berhitung dasar dengan menggunakan berbagai media. Hasil yang diperoleh melalui observasi menunjukkan hasil yang memuaskan. Dengan menggunakan penerapan model maya hasim di dalam Meningkatkan Kemampuan keaksaraan awal dan berhitung dasar, media yang digunakan yang berupa gambar binatang dan kartu huruf diberikan warna-warna yang menarik, sehingga anak ingin memegang dan melihat serta mengamati gambar tersebut. Selain itu, anak semakin antusias mengikuti pembelajaran dikarenakan guru memperagakan langsung bagaimana cara pengerjaan media tersebut dalam kegiatan Meningkatkan Kemampuan keaksaraan awal dan berhitung dasar , dan guru juga memberikan kesempatan kepada anak untuk mempraktekkan dan mendemonstrasikan di depan teman-teman yang lain, sehingga anak akan terus mengingat Meningkatkan Kemampuan keaksaraan awal dan berhitung dasar ini dan semakin antusias untuk terus mencobanya. Dari penjelasan di atas, dapat disimpulkan bahwa metode pembelajaran yang isi kegiatannya dapat ditiru oleh anak dan lebih efektif dalam upaya kemampuan keaksaraan awal dan berhitung dasar melalui penerapan model maya hasim. Anak dapat meniru apa yang telah ditunjukkan dan dilakukan oleh guru. Agar anak dapat meniru semua kegiatan yang dilakukan oleh guru, guru harus mengatur penerapan model maya hasim dalam menjelaskan kegiatannya. Penerapan model maya hasim sangat berpengaruh pada konsentrasi anak. Penerapan model maya hasim membuat anak tertarik untuk mengikuti pembelajaran, anak akan menjadi lebih antusias mengikuti pembelajaran.

\section{Kesimpulan}

Berdasarkan hasil pembahasan mengenai penerapan maya hasim dalam upaya peningkatan kemampuan keaksaraan awal dan berhitung dasar , maka dapat disimpulkan sebagai berikut :

Metode pembelajaran yang digunakan sesuai dengan situasi dan kondisi anak yaitu menggunakan penerapan model maya hasim sebagai upaya peningkatan kemampuan keaksaraan awal dan berhitung dasar dan pelaksanaannya sangat diminati anak.

Penerapan model maya hasim dalam upaya peningkatan kemampuan keaksaraan awal dan berhitung dasar sangat besar pengaruhnya terhadap anak, dengan penerapan model maya hasim berpengaruh positif anak lebih termotivasi dalam 
pembelajaran konsep huruf.

Kesulitan pada faktor pendorong dan pendukung dalam penerapan maya hasim adalah sarana dan prasarana serta seperti penataan ruangan yang kurang menarik serta cara guru dalam memimpin kegiatan sehingga anak kurang berminat dalam pembelajaran.

\section{Daftar Pustaka}

Akbar, R, \& Hawadi. (2001). Psikologi perkembangan anak - mengenal sifat, bakat dan kemampuan anak. PT Gramedia Widiasarana Indonesia: Jakarta.

Anna Yulia. (2005). Menumbuhkan Minat Baca Anak. Jakarta: PT Gramedia

Best,J.W., Kahn,J.V.(1993). Research in Education ( $7^{\star \wedge}$ Edition), New. Delhi: $\mathrm{P}^{\wedge} \mathrm{ed} \mathrm{d}^{\wedge} \mathrm{e}$ Hall.

Corbin, J., \& Strauss, A. (2007). Basics of qualitative research Techniques and procedures for developing grounded theory ( $3 \mathrm{rd}$ ed.). Thousand Oaks, CA Sage.

Dardjowidjojo, Soedjono. 2003. Psikolinguistik: Pemahaman Bahasa Manusia. Jakarta: Yayasan Obor Indonesia.

Depdiknas. 2004. Kurikulum 2004 Standar Kompetensi Mata Pelajaran. Matematika Sekolah Menengah Pertama dan Madrasah Tsanawiyah. Jakarta

Dwi Lestari 2012. Prosiding Semnas Matematika dan Pendidikan Matematika UNY. Nov 2012. 17. Linearisasi Sistem Persamaan Diferensial Parsial pada Model Epidemi

E Susilo 2013 Kegiatan Keaksaraan Keluarga Untuk Mengembangkan Keaksaraan Anak Usia Dini Jurnal Pendidikan Anak Usia Dini 1 (2) 2013

Endrianti, E. (2007). Peranan Orang Tuadalam Menumbuhkan Minat Baca Anak Sejak Dini. Skripsi UPI Banding: Tidak diterbitkan

Sri Lilis, Herlianthy and Riana, Riana and Sudaryuni, Dian (2016) Model bermain aksara dengan maya hasim (bagi anak usia 5-6 tahun). PP-Paud dan Dikmas Jawa Barat, Lembang.

Sriningsih. 2008. Pembelajaran Matematika Terpadu untuk Anak Usia Dini. Jakarta: PT Grasindo 